\title{
Research of the Category of Belief
}

\author{
Umurzakov Akhmadjon, Azimov Ulugbek, Ergashev Ulugbek, Akhmedalieva Rano, Khoshimov \\ Sanjarbek
}

\begin{abstract}
Today we are building a democratic, secular state based on the Constitution and laws, which is a reflection of the will of our people. At the same time, we must not forget that secularism does not mean atheism. We know well from yesterday's history of how human life would be bad when religion and religious beliefs were completely rejected. The danger of this ideology is that it rejects all these centuries-old values that have become an integral part of people's lives - be it written or oral, material or spiritual heritage, ethics or traditions, national outlook or way of life. As a result, human beings are deprived of their inner worlds, feelings and opinions, with which they can rely. As the "Soviet bosses" say, it becomes a "screw" of a huge state machine. In the end, such a person becomes so disgusted that he doesn't know his parents, his own nation, his people and his homeland. [1]
\end{abstract}

Keywords: "belief", "itaqada", "trust,", "belief", "faith", as "knowledge based on beliefs", "beliefs that regulate behavior", "political beliefs", "people's beliefs", "personal beliefs," “beliefs.".

\section{INTRODUCTION}

Today, the formation of healthy religious beliefs in the hearts and minds of people is an important factor in building civil society, because religious organizations are an integral part of civil society. One of the forms of social consciousness that plays an important role in the spiritual life of society is religious consciousness. Religious consciousness is such a form of social consciousness that it is a divine, imaginary form of natural and social existence. In the events of nature and society, it connects people, themselves and each other with divine powers, and expresses their will, desire, goodness or anger, hatred and punishment. Religious belief as a basic element of religious consciousness is the unconditional belief and adherence to religious beliefs, guidelines and instructions. Religious belief is a set of religious images that are in the minds of those who believe in divine powers. The basis of any religious consciousness is the religious faith.

The word "belief" comes from the Arabic verb "itaqada" which means "trust," "belief," "faith". In the broadest sense, belief is a specific psychological state, which is strongly related to the belief that a person's purpose or idea is right. At the same time, there must be different conditions for faith. In general, belief is a factor that unites individuals, groups and makes people an active member of social life.

Revised Manuscript Received on October 15, 2019.

Umurzakov Akhmadjon, Teacher of the Fergana Polytechnic Institute, Uzbekistan. (Email: ferpi_info@edu.uz)

Azimov Ulugbek, Teacher of the Fergana Polytechnic Institute, Uzbekistan.

Ergashev Ulugbek, Teacher of the Fergana Polytechnic Institute, Uzbekistan.

Akhmedalieva Rano, Teacher of the Fergana Polytechnic Institute, Uzbekistan.

Khoshimov Sanjarbek, Teacher of the Fergana Polytechnic Institute,Uzbekistan.
Religious belief means believing in an objective Being ( above human will), Belief in God, Communication directly with him, Getting help from him, the repetition of strange events and their relation to it, as well as a certain idea, faith, the belief of the holy book and the prophet, the saints.

In religious beliefs certain symbols (objects, actions, words, texts) have religious meaning. Their totality provides the formation and functioning of the religious direction. Every religion or religious direction has its old beliefs. The formation of great knowledge is inextricably linked to belief. This notion is often associated with religion alone. If one is considered that belief means faith, then a materialist, an atheist scholar, believes in something. The only difference is that the scientist believes in the power of the knowledge, while those who know themselves believe that there is a fundamental truth that is inextricably linked to the Absolute Truth and the Absolute Good. It does not matter what this basis is called (God, Allah, Brahman, Yahweh, etc.). This means that knowledge holders are also different in their beliefs, and for many centuries there is always a conflict between atheists, scholars, and believers. V. Solovev, one of the great figures of Russian philosophy of the late 19th century, said that "the belief that is not understood and understood is, first and foremost, an object that does not expect human beings (God)... He did not give the human being the ability to understand for fearing, trembling, or obeying as animals.'”[2]

It is well known that theology, philosophy and other social sciences have always been complementary. Sociophilosophical views of Eastern and Western thinkers have contributed to the enhancement of humanity's spirituality. Their vision is to help prevent negative phenomena such as religious extremism and terrorism, which are a major threat to society today.

While the basis of Western civilization is the scientific legacy of the Eastern thinkers, it is worth noting that the views of religious scholars and philosophers of the West still have their relevance. After all, the valuable ideas in their work are being objectively studied in the research work of many scholars born in our country. In this regard, the relevance of a scientifically unbiased study of beliefs in their works is determined by such objective factors. 


\section{REVIEW OF THE LITERATURE ON THE TOPIC}

The role of religion in social life and its important functions have long been the research of theologians and philosophers. This is mentioned in the works of European scholars G. Skirbekk [3], Kenterberysky [5], P.Abelyar [6], R. Bacon, U. Okkam, I. Kant [7], F. Schelling [8], S. Solovev [9], Yu.Kimelev [10], I. Jablokov [11], K. Bart, E. Jilson, J. Mariten, N. Gile [4], and others. There are traces of this theme in the works of such scholars and scholars as AlFarabi [12], Al-Biruni [13], Ibn Sina [14], Ibn Arabi [15], Ibn Rushd [16], Al-Ghazzali [17], Al-Shahrastani [18]. Also, the works of Uzbek philosophers, historians and religious scholars who are doing research in this field draw attention to various aspects of the subject. Some of them are also relevant in the researches of such scholars as H.A.Alikulov [19], A. Mansurov [20], M.Sadyk M.Yusuf [21], N.Nizomiddinov [22], A.Abdusamedov [23], Z.Munavvarov [24], Sh.B.Khahhorova [25], M. Ahmedova [26], A. Erkaev [27], I. Karimov [28], M. Hayrullaev [29], Sh.Evqochev [30], A. Choriev [31], A.Achildiev [32].

\section{RESEARCH METHODOLOGY}

In the course of the research, the following general and philosophical methods were used: historical, objectivity, abstraction, concrete, systematic analysis, comparative analysis.

\section{ANALYSIS AND RESULTS}

As there are hundreds of definitions of religion, beliefs are also given many definitions. Different members of different fields have described beliefs in their respective fields. Because of this, different definitions have emerged. But none of these definitions has been agreed upon. Here are some examples of these definitions [33]: ... Only people without faith cannot do it; only fools or people without conscience will be disloyal." N.G. Chernyshevsky.

"You need to have the courage to speak your faith." I. Sechenev.

"Everyone must be courageous in defense of their faith." Gumboldt.

"Beliefs are valuable not only because we own them, but because they are real." V. G. Belinsky.

"Any of our firm beliefs can be discarded, or at least changed, in the reason of further knowledge." T. Hexley.

"If you reject sincere, deep, unbiased beliefs in people, then I can justify in every way that you have no faith." Ya.A.Dobrolyubov.

"Beliefs cannot live beyond being active." A. Suhomlinsky.

"Belief, by its very nature, cannot be a spiritual asset without inaction." V.A. Suhomlinsky.

"It cannot be praised by hanging it on a wall." O. Balzak.

"A person who dedicates his life to his belief will be more of a human being than a researcher who discovered new metal or discovered new gas." J. Lowell.

"The unbeliever is weak, and everyone who is immoral is a stranger." Ya.E.Rep.
"It is impossible for a living soul not to have strong faith

"If my beliefs change according to the beat of my heart, it will be bad for me." F. Schiller.

"Faith is a gift from God. Don't think of it as a gift of the mind." B. Pascal.

"Keep in mind that it is the only faith that can do no work, justify, redeem, and provide refuge." M. Luther.

From these definitions it can be seen that scholars' views on the above beliefs and the conclusions they make in their own opinions are always based on goodness. We believe that belief is a criterion that gains confidence and determines the behavior of a person.

Religious belief is the inner feeling of a person to acknowledge the righteousness of God that is independent of the will of man, and to accept his instructions.

The authors were of the opinion that, apart from religious beliefs, individuals may have a special mental state that is based on belief in scientific truths. Moreover, they propagate many notions such as "knowledge based on beliefs", "beliefs that regulate behavior", "political beliefs", "people's beliefs", "personal beliefs," "beliefs." In this study, we analyzed the theological and philosophical interpretations of medieval European scholars about beliefs and religious beliefs.

At the end of the fourth century, the Roman Empire was divided into two parts. As a result, Christianity became the leading state religion. The migration of the German tribes that took place at the same time (375-568) led to the fall of the Western Roman Empire. The Age of Antiquity ended and the Middle Ages began [34].

The social conditions of the Ellada (Greece) in the Roman period led to a certain departure from politics and a loss of interest in theoretical philosophy. By this time the area of interest was mostly confined to the moral issues which were at the center of individuality. But at the end of The Age of Antiquity, interest in this "philosophy of life" faded. People began to look for something unusual in their inner world. They sought religious solutions to the problems of life. Neoplatonism (and, to some extent, stoicism) has become a manifestation of the pursuit of religion, and has laid the groundwork for the spread of Christianity.

Christianity appealed to everyone. It gave hope to everyone. In spite of having political injustice, material poverty, and physical suffering, weakening evil and willpower, the hope remains for everyone. Life on earth, Christianity argues, is part of a dramatic historical process whereby everyone will expect a just reward for the injustice and suffering in life. Above them is God, the Creator, the Kind, the righteous spirit.

In the Middle Ages philosophy and theology were the types of intellectual activity that claimed to be temporary. Therefore, the topic of the relationship between belief and thinking has become one of the main topics. These two types of spiritual and intellectual activity had to agree on what issues were related to philosophy and what matters were to theology.

It is possible to say that Christianity has taken the following three main points to the philosophical and 
intellectual environment, they are: 1) The idea that "human is the center of all things"; 2) a linear idea of history; and 3) The next is the concept of God as Creator and Person.

For Greek philosophers, human was considered to exist in the whole and in outer space with other creatures. The human being was sufficiently higher than the others but it was considered a separate, privileged creature. It is thought that stone and soil, plants and animals, people and gods exist in one complete universe. This is not the case with Christianity. God is the Creator above this world. The whole earth - with its stones, plants, animals and people - was created by God as the dwelling place for man to be secure. The universe is secondary to humans and God. Everything in the structure of the world is concentrated around the road leading to man's refuge on earth.

At that time, Christianity's ideas of refuge and sin were substituted for Greek spiritual ideas (about good life and good qualities). There was talk of making everyone safe. Humans are more precious than any other living creature and all people have one supreme value. Such an understanding would mean that the stoic ideas of natural law, universal solidarity and equality coincided with Christianity. There is a common law for all - the law of God. All humans are equal, since they were created by God in his image.

Man is central in both cosmological and axiological terms. For this history is important, not nature. History is not a circle, as the Stoics imagined it, but a line. History moves towards Judgment Day: the creation, the sin of man, the birth, life and resurrection of Jesus Christ, the struggle between sin and refuge.

With the advent of Christianity, the scope of epistemological issues has also expanded. In addition to issues of what we can know, there are questions about what we can rely on religiously, that is, the question of the interrelationship of religious beliefs and wisdom, Christian sincerity, and Greek thinking. They served as the focal point for Christian theology.

Among the Christian theologians there were those who believed that Christianity and Greek thought were fundamentally incompatible with each other, and that Christian belief was not supposed to be based on philosophy or reasoning. Tertullian (ca. 160-222) reacted negatively to philosophy. For Tertullian, belief is more free than thinking. This view represents a critical point in understanding the relation between religious (Christian) beliefs and worldly wisdom.

The relatively moderate view implies an area that is somewhat general in belief and thinking. Some early Christian theologians advocated this view. In their view, belief prevails in the epistemological sense. If there is a conflict between belief and reasoning, belief is true. This view is typical of many Christian theologians, from Augustine to Thomas Aquinas. But there were a number of approaches within it. One of them is that belief has the advantage in this sense that it makes it possible to think. This means that people without sincerity and faith can become "blind" to the most important aspects of life. Augustine made the same point.

Augustine (354-430) declared that belief in the divine authority recorded in the Bible is the basis and source of

human knowledge. The sin that Adam and Eve inflicted on all of humanity made the human mind irreparable and severely undermined its power. From that time on, the human mind must seek the support of its divine revelation. According to Augustine's famous phrase (several of his letters are published) - "Believe in for understanding" religious belief must come before understanding.

Another approach is that faith prevails only on the fundamental truths of Christianity. On the whole, belief and thinking are free and have the same status. In part, they deal with their specific problems and, in part, to their common problems. For them, there is a harmony between the common beliefs and thinking. For example, this is the question of the existence of God, while the essence of God is in the field of sincerity. The interconnectedness of belief and thinking is evident in the theology (philosophy) of the Italian philosopher Thomas Aquinas (1225-1274).

Thomas divides religious beliefs into types that can be understood (God exists, God is one, human soul is eternal, and so on) and misunderstood with intelligence inexplicable (creation of the world, the trinity of God, the doctrine of the first sin, and so on). According to Thomas, the former are both theological and philosophical, and the latter are only the themes of faith and theology, because of their superiority of reason.

Philosophy and theology are independent sciences because the basic principles of theology (religious doctrines) and the basic principles of reason (the laws of formal logic) do not follow each other. But theology uses the basic principles of philosophy and reason in order to approach the understanding of the human mind and to show that it is not contrary to reason. If it is necessary, it should avoid objections against them. Therefore, "philosophy is the servant of theology." [36]

It should be noted that, although in Thomas Aquinas's teaching, it is available a combination of faith and reason, religiosity and secularism, when it comes to the essence or nature of God, Thomas believed that we can illuminate him with revelation and faith, not worldly wisdom.

The Franciscans, especially the British, who were constantly in competition with the dominant, brought in Duns Scott (1270-1308) the greatest enemy of Thomas. Dunce considers religious beliefs to be logically incompatible. The doctrine of the Trinity, the divine image and the immortality of the soul can only be based on faith The mind cannot prove it. Beliefs are not linked to knowledge.

Dunce blames Thomas's views on pantheism. In his view, the will of God is not expressed in purpose, but rather, "the will is above the mind."

The scholastics of medieval "realism" found its commentators in the form of Anselm of Canterbury (10331109) and his students.

Anselm believed that belief was a prerequisite for rational thinking. He is known for his statement: "I want to be smart and then not to be a believer but to be a believer and then to be wise." He thinks that the existence of God stems from the 
concept itself. Anselm was called the first scholast because he put forward the idea that scholastic philosophy must be used wisely to confirm (prove) Christian truths. While he emphasized the importance of the mind when it comes to reason in belief, he put faith above intelligence. It relies on the empirical interpretation and the Aristotelian hypothesis that without the first line, the whole line cannot be itself. According to this logic, not only does God exist, but he is equal to absolute happiness, perfection, and existence.

According to the ontological hypothesis of Anselm, God exists, and nothing grand can be imagined. The idea that there is a conscious acknowledgment of the existence of God, but the denial of its existence, would be to acknowledge something higher (but there is not) than God. So the existence of the word of God proves the existence of God. The scholastic proof of the existence of God was rejected by Thomas Aquinas and his contemporaries, but was developed by such thinkers as Descartes, Leibnitz, Hegel and Brady. Anselm continued the philosophical thoughts of Plato and Aristotle on logic. Anselm pointed out that the balance between belief and reason can be drawn from Christian truths.

Therefore, the teaching of Anselm answered primarily the interest of the church with the attitude of faith to the mind. According to Anselm, there is no need to understand for believing, but it is necessary to have belief for understanding. The Catholic faith must not be violated. Knowing does not increase the validity of religious beliefs, since they in themselves are enduring. There must be no question that a Christian should ask whether the belief that the Catholic Church proclaims is correct or not. A believer should love religion and live according to its teachings and study the basics of its correctness. If he can figure out the basics of religion for himself, he should thank God; if he cannot do so, he should humbly bow his head and pray. This subordination of knowledge to faith is combined with the high appreciation of intellectual knowledge in Anselm's works. Anselm considered himself to be one of those people who could find a rational answer to the basics of their beliefs. In his theological rationalism, Anselm was far away. He explained that one can understand the notions of the mind not only of the existence of God but also of the Trinity. In his "Monologium", Anselm tried to rely solely on the rationale, leaving aside the testimony of the Trinity in the religious book.

In the work of "Prolog", Anselm developed the evidence of the existence of God, which later became famous. The argument is that the existence of a god is only mediated by the deduction from a single conception of God, or through the disclosure of the contents of the concept [37].

The moderate doctrine of Anselm was readily acknowledged for its connection with the practical ideological problems of the church and supported by the supreme church authority.

The struggle between realism and nominalism that flourished in the eleventh century brought not only the extreme opponents of these two movements, but also the thinkers who sought to reconcile the two movements. The most prominent of these was the famous French philosopher and theologian Pierre Abelard (1079-1142).
Contrary to the Anselm, Abelard analyzed the relationship of faith and reason and taught that belief should be based on mental understanding and that it was necessary to deal with the texts in the Bible. According to the doctrine of the Two Truths, beliefs about things that we do not experience and that are outside the real world are within our belief. According to Abelard, the science of dialectics or speech is logic. Abelard believed that universal concepts do not exist as separate objects in real reality. But they have the status of a "world" in the field of intellectual knowledge and constitute a unique third conceptual world. Abelard expressed his interpretations, pointing to contradictions in Christianity. Because these interpretations differed from those that were officially recognized, Abelard was twice condemned by the church. In his work "Yes and No" he argued that human beings have the right to live with their own intellect. The medieval English philosopher and naturalist Roger Bacon's scientific researches (ca. 12141294) influenced greatly his philosophical views. According to Roger Bacon, these are the parts of philosophy: mathematics, physics, and morality. Physics includes optics, astronomy, alchemy, medicine, and technical knowledge. He stood in the position of moderate realism on the important issue of medieval philosophy - the essence of universalism. To him, there are only certain things. But he denied the existence of universalism before things.

According to Roger Bacon, there are three types of knowledge: trust in authority, thinking and experience. It is not enough for knowledge unless authority is based on thinking. Furthermore, the thinking can only be trusted if it rely on experience. This also applies to mathematics. "As for the issue of judgment, the situation is that it is impossible to differentiate the nonsense from the evidence without examining the conclusions through experimentation Although Aristotle acknowledged comparison as a source of knowledge, there have been occasions when the simple experience taught better than any comparison." "There is an unnatural, incomplete and not perfect experience in its activities." Bacon wrote in his "Opus Tertium" -"All of the intellectual knowledge and the skills to conduct experiments that are superior to the arts are the princess of all disciplines" [39].

Roger Bacon believed that knowledge comes first of all through external senses. Roger Bacon strived to reform theology, arguing that it is dependent on philosophy and scientific knowledge. Roger Bacon sought to bridge the contradictions between theology and philosophy, beliefs and cognitive relations. In his view, knowledge and faith are the product of early divine prophecy, so they are not at odds with each other. Knowledge strengthens beliefs, so that philosophy becomes "Christian knowledge." On the basis of the undeniable truths given by God, philosophy becomes the guide of all sciences. This teaching of Roger Bacon was also consistent with his political views. In his view, all nationswho embrace Christianity, the only true religion in the future, will unite in one state. Religious strife and massacre will cease in this country. Peace and order will be 
established. The highest class of this state is the clergy class, the spiritual leaders of the society. The second is the state's military defenders, and the third is peasants and artisans. The clergy must act as scholars who know the basics of science.

In a general sense, Bacon did not oppose religion. He declared the philosophy's dependence on matters of faith. He says that because miracles do not happen today, the only way to attract those who do not believe in religion and to reject their enemies is the power of philosophy. But objectively, Bacon's entire work contributed to undermining religious faith and raising scientific knowledge.

\section{RESULTS \& DISCUSSIONS}

English philosopher William of Ockham (ca. 1300-1349), one of the great representatives of the nominalism, completely rejected the connection between philosophy and theology. Philosophy is not able to prove the doctrines of religious beliefs. Because Philosophy cannot be the basis of belief. Philosophy, for example, claims that it cannot prove the existence of God. According to Ockham, the existence of God cannot be proved by rational evidence. It derives from the truth of the holy book of theology.

Therefore, theology is in conflict with the philosophy that stems from the truth of the mind [40]. Ockham's philosophical works were inextricably linked to his political activities. They were in sharp opposition to orthodox ideology. Ockham has deepened Scott's views on issues of religion and reason, revelation and knowledge, which is a central issue of medieval philosophy. Just as church authority is limited to religious matters, theology must rule only in matters of faith based entirely on revelation. The mental proof of belief is impractical and futile. There is no proof that God exists or any of His attributes. Only the beliefs of religion can be trusted. Theology would thus be dismissed as a "science," while philosophy would be free from its guardianship. Theology and the relationship between man and God are primarily based on Bible study and Bible faith. In short, nominalism leads to a markedly differentiation of reason and belief, and to a certain extent a rejection of metaphysics and speculative theology. Consequently, in some sense, the center of intellectual endeavors shifts from philosophy to experimental subjects. In the worldview of the famous Russian philosopher, poet, publicist and critic Vladimir Sergeevich Solovev (18531900) the influence of Shelling, Hegel and Schopenhauer was powerful. The purpose of philosophy is to uphold the social and religious ideal, and the goal of intellectual development of mankind is to integrate science, philosophy and religion; he believed that belief was the basic stage of knowledge, and that the basis of morality was conscience, compassion, and faith in God. [41]

Karl Bart (1886-1968), a Swiss Protestant theologian and co-founder of dialectical theology, made his first Reformed theology in the spirit of Calvinism (that is, he predicted that God would "deliver" the fate of some, and that "the curse" may be fated by some) supports the update. Bart, as one of the founders of dialectical theology, opposed the Catholic philosophy to philosophically prove the existence of God, to derive religious belief from the "results of a pious spirit," and to rationalize any religious belief. According to him, the belief is a dual aspiration between "yes" and "no", boldly entering the unknown. Human knowledge and the essence of creation are different. Bart demanded social responsibility from the church and distinguished it as a "true" and "unreal" church.

Jacques Maritain (1889-1973), a French philosopher of Thomism, considered the philosophy of the modern era as a crisis and degradation of philosophical thinking. Luther, Descartes, and Rousseau, in their view, believe that religion is the cause of thought and emotion, the triumph of subjectivism, and then moral and social chaos prevails. The only way to overcome this was to go back to the medieval "clarity of thought" and objectivity. Criticizing intuitionism, Mariten, as a representative of the Catholic religion, sought to "reconcile faith and reason, theology, and philosophy."

The French religious philosopher, the leading figure in the Thomism movement, Étienne Gilson (1884-1978), considered the main task of his research to revive Thomas Aquino's doctrine of the need for a harmonious combination of reason and religion. He recommended an existential interpretation of the divine existence, such as Mariten. In this interpretation, the divine being is manifested as the act of pure existence, which leads to the emergence of all things in nature and in the world of society.

According to Wilson, at different times philosophers interpret the universe as distinct. In this sense, the historian deals with an eternal philosophy that never ceases to exist in its path to existence. From this point of view philosophical errors appear as the result of the generalization of relative, imperfections about the world and man. According to Wilson, in ancient philosophy, Plato, Aristotle, and neoplatonists have done much in the field of knowledge of existence. The integration of this knowledge with Christianity by patriarchs and medieval thinkers has been described as an effective step by which Gilson defined a strategy for the unity of philosophy and theology.

Gilson considered the pinnacle of medieval thought in the doctrine of Thomas Aquino. He regarded the later state of the Renaissance and the New Age philosophy as a process that led to negative consequences and a compromise between philosophical and theological wisdom and science. In his view, the science of Descartes and Kant developed in the tradition of positivism in science, and antiscientism emerged as the polar opposite. The struggle between them Wilson said, is the most important feature of 20th-century Western philosophy, and can only be eliminated by the rebuilding of Thomism. Jilson believed that the future culture of the modern era was associated with the restoration of the influence of religious and moral values.

\section{CONCLUSIONS}

From the aforementioned interpretations, we can conclude that philosophically religious belief is a particular condition of individual, group, and community (belief subjects) beliefs, beliefs, and hopes, as belief in something or someone as the main element of religious consciousness. 
Theologically, religious belief is an absolute belief in God, who is regarded as the most perfect and powerful miracle power that has ever created the world and man, the ability to reveal knowledge about Him. There is also a philosophical-theological approach, according to which belief in knowledge, and above all belief in the existence of God, does not need to be based on rational evidence as the core of that knowledge.

The study investigated a number of functions and tasks of beliefs as an integral part of social life and revealed their importance in community life.

Firstly, religious studies, philosophy, and other social sciences have always been complementary.

Secondly, different situations, knowledge and ideas related to the rise of the human spiritual world are important elements of belief, philosophical analysis of knowledge and ideas that have become beliefs are the result of social practice, the product of human knowledge, and beliefs in general are a key component of human thinking.

Thirdly, in the current era of globalization, it is important to preserve the purity of our spirituality. Religious and religious beliefs play an important role in the successful resolution of such processes, spiritual and educational reforms in Uzbekistan, the preservation of national-cultural and spiritual-enlightenment values.

Fourthly, the commonality of beliefs and spirituality, the question of the individual and his or her beliefs, is an important issue today, and the formation of a healthy religious belief in the hearts and minds of people is an important factor in building civil society.

Fifthly, the factors that shape religious beliefs and enlightenment, the importance of religious factors in shaping young people's thinking, as well as their sensitivity to religious beliefs in times of difficult and complex processes of the time, are of vital importance.

\section{REFERENCES}

1. Karimov I.A. High spirituality is an invincible force. Tashkent: Spirituality, 2010. -P. 93.

2. V. Soloviev. Dispute about justice. -Moscow-Kharkov: "EXMO-PRESS", "FOLIO", 1999. -P. 807-808.

3. G. Skirbekk, N. Gile. History of Philosophy. -Moscow: "GIC Vlados", 2000.

4. G. Skirbekk, N. Gile. History of Philosophy. -Moscow: "GIC Vlados", 2000.

5. Anselm von Canterbury. Cur deus homo? Munchen, 1937.

6. Abelard P. The story of my disasters. -Moscow: 1959.

7. Kant I. Treatises and letters. -Moscow: 1980.

8. F. Schelling. Op. T. 1. -Moscow: Thought, 1987.

9. V.S. Soloviev. Dispute about justice. -Moscow Kharkov: "EXMO-PRESS", "FOLIO”, 1999.

10. Kimelev Yu.A. Modern Western philosophy of religion. -Moscow: 1989.

11. Fundamentals of religious studies. Edited by I.N. Yablokov. -Moscow: High School, 1998.

12. Abu Nasr Farabi The City of Virtuous People. Tashkent: Heritage, 1993.

13. Beruni, Abu Rayhan. Monuments from ancient peoples // Beruni A.R. Selected works, Volume I, - Tashkent: 1968.

14. N. Siraisi. Avicenna in Renaissance Italy: The Canon and Medical Teaching in Italian Universities after 1500. Prisenton, 1987.
15. Ibn Arabi. Gems of wisdom (chapters). Translation A.V Smirnova. V.Kn. M. Stepanyants. Philosophical aspects of Sufism. -Moscow: "Science", 1987.

16. G.F.Hourani. Averroes on the Harmony of Religion and Philosophy. London, 1961.

17. Ghazali, Muhammad Abu Hamid. Ihyo-ul-ulum / Translation by A. Mansur from Arabic // Kamalak. Literary and Critical Annual Collection. - Tashkent: Young Guard, 1990.

18. Muhammad ibn AbdulKareem ibn Ahmad AlShahrastani. Al-Milal va-Nihal. -Egypt: 1977.

19. Alikulov X.A. Ethical views of philosophers of Central Asia and Khorasan (XIV-XV centuries). -T.: Fan, 1992.

20. Mansurov A. Aqoid texts. - Tashkent: Publishing and Publishing Association "Tashkent Islamic University", 2006.

21. Sheikh Muhammad Sodiq Muhammad Yusuf. Sunni doctrines. - Tashkent: "Sharq", 2008.

22. Nizomiddinov N.G. Ancient history, religious beliefs, culture of the peoples of South, Southeast and East Asia. (Chrestomatia). - Tashkent: 2010.

23. Abdusamedov A.E. Philosophy of Religions. - Tashkent: 2010.

24. Munavvarov Z. Secular state and religion. - Tashkent: 2003.

25. Shakhnoza Kakhharova. Global spirituality is the ideological basis of globalization. - Tashkent: Tafakkur, 2009.

26. Ahmedova M. Fundamentals of Philosophy - Tashkent: Uzbekistan, 2006.

27. Erkaev A. Spirituality and development. - Tashkent: "Spirituality", 2009.

28. Karimov Ibrohim. Faith as a spiritual state. -Toshkent: "Fan", 1991.

29. Khairullaev M.M. Renaissance and Eastern philosophers. - Tashkent: "Fan", 1971.

30. Yovkochev Sh. et al. History of religions of Central Asia. -Tashkent: Oriental Studies, 2006.

31. Choriev Anvar. From knowledge to idea, from idea to belief. // J. Communication. - Tashkent: 2002.

32. Achildiev A. National Ideas and Interethnic Relations. Tashkent: Uzbekistan, 2004.

33. The World of Thought: Aphorisms and Wise Words of Our Motherland and Foreign Authors / Vorontsov Composition; Sh Translate Abdurazzoqova. - Tashkent: Literature and Art Publishing House, 1981. - p. 126128.

34. "Middle Ages" - medium aevum - the name is retrospectively given by those who have viewed the time period between the Ancient ("ancient") and the Renaissance ("revival" of antique culture) as the Age of Ignorance. // Gunnar Skirbekk. Nils Gile. History of Philosophy: A Handbook for Higher Education Institutions / Translation. A. Deletroz, Z. Tursunova and V. Kuznetsov. -Tashkent: East, 2002. -P. 169.

35. Tertullian. Selected Works. -Moscow: 1994; History of Philosophy. -Moscow: "GIC Vlados", 2000, p. 178.

36. Fundamentals of Philosophy. Text of lectures. Tashkent: Publishing and Publishing Association "Tashkent Islamic University", 2005. pp. 89-91.

37. History of philosophy. -Moscow: 1941. Volume-1, pp. 427-429.

38. Abelard P. The story of my disasters. -Moscow: 1959. P. 96-103.

39. History of philosophy. -Moscow: 1941. Volume $-1, \mathrm{p}$. 472 . 
40. The encyclopedic dictionary of philosophy. - Tashkent: "Sharq", 2004. -P. 309.

41. Philosophy: Textbook for universities / Ed. prof. V.N. Lavrinenko, prof. V.P. Ratnikova. -Moscow: UNITY, 2000, p. 286. 